\title{
Bcr-Abl Kinase Inhibitor PF-114
}

National Cancer Institute

\section{Source}

National Cancer Institute. Bcr-Abl Kinase Inhibitor PF-114. NCI Thesaurus. Code C130033.

An orally bioavailable, Bcr-Abl tyrosine kinase inhibitor, with potential antineoplastic activity. Designed to overcome resistance of tumor cells to second generation Bcr-Abl inhibitors, PF-114 targets and binds to the Bcr-Abl fusion oncoprotein, including those fusion proteins with the 'gatekeeper' resistance mutation T315I, an amino acid substitution at position 315 in Bcr-Abl from a threonine (T) to an isoleucine (I). This inhibits Bcr-Abl-mediated proliferation of, and enhances apoptosis in, Philadelphia chromosome-positive (Ph+) hematologic malignancies. The Bcr-Abl fusion protein is an aberrantly activated tyrosine kinase produced by leukemia cells that contain the Philadelphia chromosome. 